Joseph A. Ritter is a research officer at the Federal Reserve Bank of St. Louis. The author is grateful to Brent Moulton and Robert Parker for helpful comments and discussions. Any remaining errors should be attributed to the author. Joshua Feldman, Daniel Steiner, and Paige Skiba provided research assistance.

\section{Feeding the National Accounts}

\author{
Joseph A. Ritter
}

M odern market economies are probably the most complex institutions ever devised. Both the private and public sectors need reliable information about the condition of the economy, and systems for tracking the economy are ubiquitous, ranging from trade magazines to measurements of help-wanted advertising to unemployment insurance claims to the consumer price index (CPI). Even weather data has an important place in understanding what is happening in the economy.

In the United States, by far the most complex of these tracking systems is the National Income and Product Accounts (NIPA). These accounts attempt to track income and production for the entire U.S. economy. The accounts are compiled by the Bureau of Economic Analysis (BEA), an agency of the Department of Commerce. Some sense of the scale of this undertaking comes from the numbers involved: At this writing, more than 130 million people are employed by more than five million firms and several thousand governmental entities to produce a gross domestic product (GDP) of about $\$ 9$ trillion.

Every macroeconomics course presents some of the abstract accounting principles that underlie the NIPA. Most introductory macroeconomics texts devote a chapter to these principles but give almost no attention to the raw data that fill in the blanks in the accounting framework. In fact, few economists have more than a superficial knowledge of how deeply BEA is willing to dig to produce plausible estimates. There are a number of reasons BEA's sources of data should be more widely understood. First, a sense of the complexity of the raw data emphasizes the importance of the national income accounting system itself; without the organizational principles devised by Simon Kuznets and others, those interested in the overall condition of the economy would find themselves overwhelmed by its sheer complexity. John Haltiwanger (1997) described the impression many economists have of the NIPA: "This depiction [of the NIPA] causes one to imagine that aggregate statistics emerge from some great black cauldron, mixed together with data from an alphabet soup of surveys (p. 68)." Partly, this impression is inevitable, given the extent and complexity of the task. But it also comes from the fact that the data-collection system behind the NIPA is closely tied to the structure of the accounts; there is no overarching database design from which NIPA statistics are derived. Instead, major statistical programs were motivated by and designed around specific NIPA tables (though, of course, these statistical programs provide data for other purposes as well).

Second, the data BEA uses to construct the NIPA are generally reliable, but they are far from perfect. They may be inaccurate, or they may not be precisely what are needed. Indeed, for quarterly estimates of some components, no source data are available, and BEA must substitute judgment and statistical methods. This is especially true of quarterly estimates published shortly after the end of the quarter, as data collection and processing often take more than one or two months. Furthermore, since the NIPA are the result of a complex process based on many inputs, it is impossible to construct formal measures of their statistical reliability, as is done for the unemployment rate, for example. ${ }^{1}$ In the absence of formal measures of statistical reliability, consumers of NIPA statistics should have at least a passing understanding of how errors can arise from data inputs to the NIPA.

Third, federal statistical programs overlap extensively in the sense that different press releases rely on the same raw data. The NIPA are just the most processed form of the data. Virtually every major statistical release feeds data into the NIPA. A data consumer should understand the extent to which the figures on the monthly GDP press release are simply new, though extremely useful, packaging for information that was in last month's headlines.

Fourth, economists often make comparisons of the economy's performance during different periods.

\footnotetext{
1 The unemployment rate is calculated from answers to yes-or-no questions posed to a systematic sample of U.S. households by the Current Population Survey. The measured unemployment rate is essentially a sample mean, so it is easy to estimate its standard error (approximately 0.11 percentage points).
} 
Table 1

\section{Main Census Bureau Surveys Used in the NIPA Annual Estimates}

\begin{tabular}{|c|c|c|c|}
\hline Survey & Sample & Main Data Used & Main GDP Components Affected \\
\hline Annual Retail Trade Survey & 22,000 retail firms & Sales, inventories & Consumption of goods, inventory change \\
\hline American Housing Survey & 55,000 homes & Occupied housing, rents & Housing consumption, rental income \\
\hline Current Population Survey & 50,000 households & Occupied housing & Housing consumption, rental income \\
\hline Service Annual Survey & $\begin{array}{l}\text { 30,000 service } \\
\text { businesses }\end{array}$ & Sales & $\begin{array}{l}\text { Consumption of services, } \\
\text { software investment }\end{array}$ \\
\hline $\begin{array}{l}\text { Annual Survey of } \\
\text { Manufactures }\end{array}$ & 55,000 establishments & Shipments, inventories & $\begin{array}{l}\text { Fixed investment, inventory change, } \\
\text { capital consumption }\end{array}$ \\
\hline $\begin{array}{l}\text { Annual Wholesale } \\
\text { Trade Survey }\end{array}$ & 7,100 wholesale firms & Inventories & Inventory change \\
\hline $\begin{array}{l}\text { Annual Survey of } \\
\text { Government Finances }\end{array}$ & $\begin{array}{l}\text { All state and local } \\
\text { governments }\end{array}$ & Miscellaneous & $\begin{array}{l}\text { Government consumption and investment, } \\
\text { consumption of services, indirect } \\
\text { business taxes }\end{array}$ \\
\hline
\end{tabular}

There has been considerable debate, for instance, about whether the U.S. economy was more volatile during the nineteenth and early twentieth centuries than since World War II (see, for example, Romer, 1999). Another example is the debate about the slowdown of productivity growth that started during the 1970s and may or may not have ended. One question always arises in these comparisons: Do apparent differences between two periods reflect actual changes in the economy, or do they result from inadequacies or changes in data-collection procedures? An understanding of the present procedures is, therefore, a necessary starting point for these comparisons.

Finally, data collection is not free. Large shares of the budgets of the statistical agencies involved in the production of the NIPA are devoted to data collection. Changes in the agencies' budgets affect data-collection procedures for better or worse. Furthermore, not all of the costs are borne by the statistical agencies. Those who are asked or required to provide data sometimes bear significant reporting costs. In addition to budgetary decisions, therefore, policymakers must make choices about how large a burden the private sector will be asked to bear. To determine how much of society's resources should be devoted to data collection for the NIPA, a policymaker should understand the weaknesses of the existing raw data, as well as the magnitude of the data-collection task.

Another aspect of the resource allocation issue has been highlighted by Haltiwanger (1997). Ideally, the major data collection efforts behind the NIPA would produce a database that could be used to study the economy using various approaches, including the NIPA. Instead, as mentioned above, the structure of data collection for the NIPA is closely tied to the structure of the accounts, and, therefore, it often is rather difficult to use the data in a different analytical framework. Although the micro data used to build the NIPA generally are available to researchers, budgetary issues frequently mean that surveys do not touch on aspects of firms' behavior that are of great interest to social scientists, but unimportant for assembling the NIPA. In particular, Haltiwanger and others have argued that it is important to be able to track the behavior of individual economic entities over time, but doing so with current data sources ranges from difficult to impossible, depending on the sector and the question under study.

This article's objective is to survey the main data sources currently used in the NIPA. It is not primarily an article about methodology, but focuses instead on the raw inputs to the process: Who is answering what kinds of questions? Fortunately, a relatively small number of sources account for most of GDP. Subsequent sections take for granted a basic understanding of the logical structure of the NIPA. ${ }^{2}$ The next section discusses the structure of the NIPA from the standpoint of the flow of information over time, followed by synopses of the data used in the product account, the income account, quarterly estimates, and price adjustment.

\footnotetext{
2 A basic discussion of the accounts can be found in virtually any macroeconomics text such as Mankiw (1999) or Abel and Bernanke (1997).
} 


\section{THE NIPA ESTIMATES}

The NIPA are a double-entry accounting system; the dollar values of income and production for a given quarter or year should be the same. Since production and income are calculated separately, using largely separate data sources, a reconciling entry, the statistical discrepancy, appears in the income account. From 1989 to 1998, the absolute value of the statistical discrepancy for annual estimates averaged 0.5 percent of GDP. It is BEA's judgement that the product side of the accounts is more accurate, and, therefore, GDP is defined as the sum of product-side components.

There are really three tiers of GDP estimates. About every five years, benchmark estimates incorporate the most comprehensive information. ${ }^{3}$ The benchmarks are definitive estimates for a given year. For present purposes, the most important aspect of the benchmark estimates is easily described: It is the use of information from the quinquennial economic censuses. There are censuses of manufacturing; services; retail trade; wholesale trade; construction; transportation, communications, and utilities; mining; finance, insurance, and real estate; and state and local governments. The censuses attempt to gather detailed information from every establishment engaged in a particular type of activity, allowing BEA to pin down precisely the level of economic activity in a given sector.

Between benchmark estimates and following the most recent benchmark year, the pattern of changes from year-to-year comes from annual estimates. The annual estimates incorporate information from data sources, such as tax returns, that are available annually, and from surveys with smaller samples of establishments (compared to the economic censuses). Estimates of the pattern of economic growth during the year - the quarterly GDP estimates - are based on still less comprehensive and, for the most recent quarters, incomplete data. The quarterly estimates are revised to be consistent with the annual estimates once the latter have been compiled.

Revisions of GDP estimates are made on a similar schedule, but the differences among benchmark, annual, and quarterly GDP estimates should not be thought of primarily as revisions; they are different estimates, derived from largely different sources. The three-tiered structure of data collection and estimates ensures that GDP estimates do not drift too far off track, while avoiding the expense of collecting exhaustive data for every quarter.
This overview focuses primarily on the construction of nominal or current-dollar GDP. Real GDP is discussed briefly at the end of the article. In general, this means that the thorny issues of price change do not arise. ${ }^{4}$ Components of the income side of the accounts typically are not adjusted for inflation, in any case. Most of the article also concentrates on the annual estimates. When sources differ for the most recent year or years (usually because of data availability lags), the article concentrates on the data that ultimately determine the annual estimate for a given year.

\section{THE PRODUCT ACCOUNT}

U.S. Department of Commerce papers (1990, 1998) are the main pointers to data sources for the various NIPA entries in this and the following sections. Most of the information on the data sources themselves can be found on the responsible agencies' web sites, primarily <www.census.gov > and $<$ www.bls.gov $>$. Figures 1,2 , and 3 show the relative sizes of the most important components of GDP and, by implication, the importance of the data sources feeding into them. Figure 3 also summarizes the most important data sources discussed below.

\section{Personal Consumption of Durable and Nondurable Goods}

For annual estimates, the most important source of data for the calculation of consumption expenditures is the Annual Retail Trade Survey, conducted by the Census Bureau. This survey currently covers about 22,000 retail firms, which report their sales and end-of-year inventories (used in the calculation of change in private inventories). For 1998, personal consumption expenditures based mainly on the Retail Trade Survey totaled about $\$ 2.0$ trillion. ${ }^{5}$ GDP was about $\$ 8.8$ trillion in

\footnotetext{
${ }^{3}$ Most conceptual revisions and methodological improvements are introduced at this time.

${ }^{4}$ Estimation of price change for product-side GDP components is discussed in Seskin and Parker (1998), Triplett (1997), and U.S. Department of Commerce (1998).

${ }^{5}$ Information required to divide total retail sales into sales to persons, businesses, and governments is based largely on the most recent inputoutput tables. The input-output tables themselves are based primarily on the economic censuses. A similar allocation among purchasers must be accomplished in various other parts of the NIPA, when the source data come from entities that serve more than one category of buyer.
} 


\section{Figure 1}

\section{Personal Consumption Expenditures}

1998 Annasi Estimates

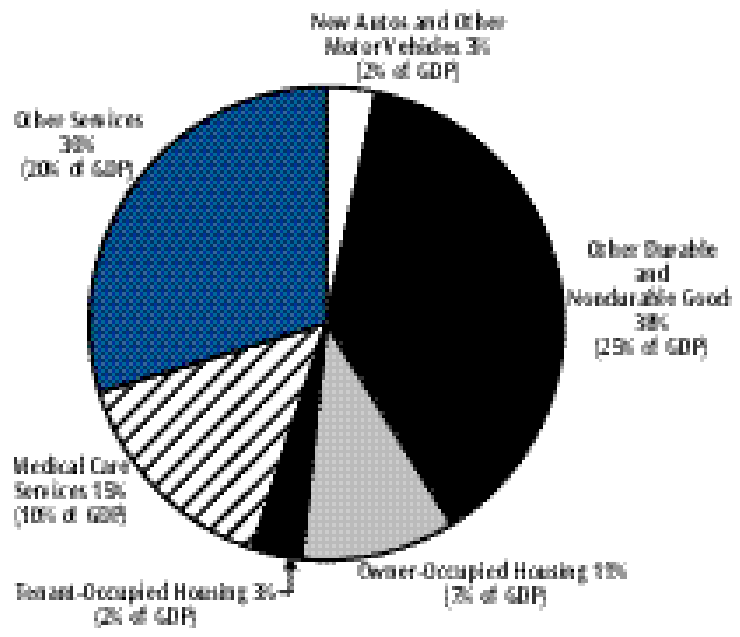

\section{Figure 2}

\section{Gross Private Domestic Investment}

1998 Anmaal Estimates

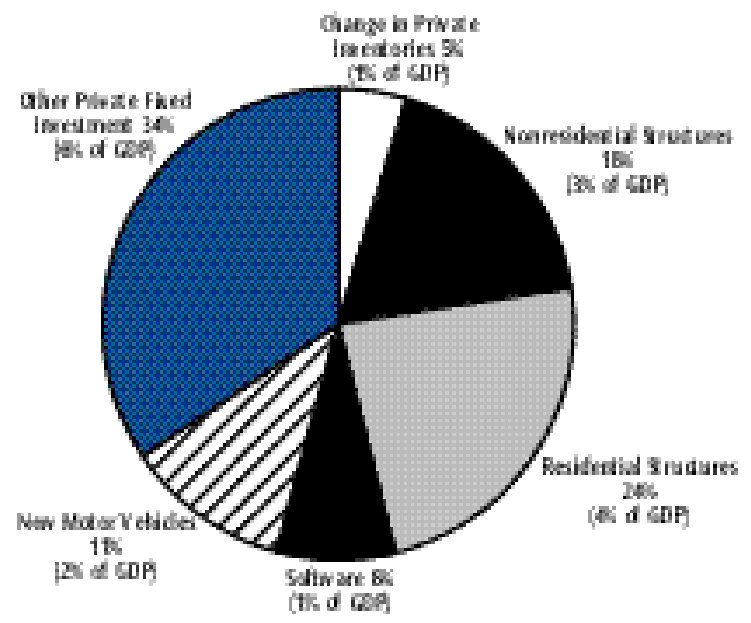

1998. (1998 figures reported in this article are based on the October 1999 Comprehensive Revision of the National Income and Product Accounts.)

The Annual Retail Trade Survey is considered a reliable data source, but, nonetheless, illustrates the kind of weakness in source data that can induce errors in the NIPA. First, ordinary sampling varia- tion comes from using a sample of firms rather than every firm to make the estimates. ${ }^{6}$ Second, there are nonsampling errors caused by nonresponse, mistakes, and so forth. The Census Bureau reports that 11 percent of reported national annual retail sales are imputed because of internal inconsistencies or errors in the raw survey data. ${ }^{7}$ Imputations are, of course, less reliable than actual data, though it is generally impossible to gauge precisely how much less reliable.

A perennial problem with business surveys is maintaining a representative sample as the underlying population of businesses evolves. The samples are based on payroll and business income-tax return records, but there is a six-nine month lag between when a business files for a taxpayer identification number and when the information is sent to the Census Bureau.

Much of the information about new auto expenditures (\$91 billion in 1998) comes from trade sources in the motor vehicle industry. In particular, these sources provide information about the number of vehicles sold domestically, list prices, and type of purchaser. The latter is used to determine how to split vehicle sales into personal consumption, business investment, and government investment. Additional information on dealer discounts, sales taxes, and transportation charges comes from other sources. New light truck expenditures $(\$ 83$ billion in 1998) are handled in much the same way, except that the starting point is the value (rather than number of vehicles) of new light truck shipments from the Annual Survey of Manufactures.

\section{Personal Consumption of Services}

The single largest item in most consumers' budgets is housing. Housing services accounted for $\$ 856$ billion of 1998 GDP. The Census of Housing,

\footnotetext{
${ }^{6}$ Sampling variability is not particularly large relative to the level of retail sales, but when the sample changes from one survey to the next, it makes up a much larger proportion of the change in sales. In other words, sampling variation ultimately has a larger impact on growth rates in the NIPA than on levels.

7 "Imputation" refers to the substitution of estimates for missing or clearly incorrect data. Imputation may be used to fill in missing or incorrect survey responses, as here, or, as the term is usually used in the NIPA, to provide a substitute for an accounting entry for which no direct data are available. The imputation can be based on previous behavior of the economic unit under study, the behavior of similar units, or on a theoretical construct. An example of the latter is the treatment of services produced by owner-occupied housing described later.
} 
NIPA Data Sources, 1998

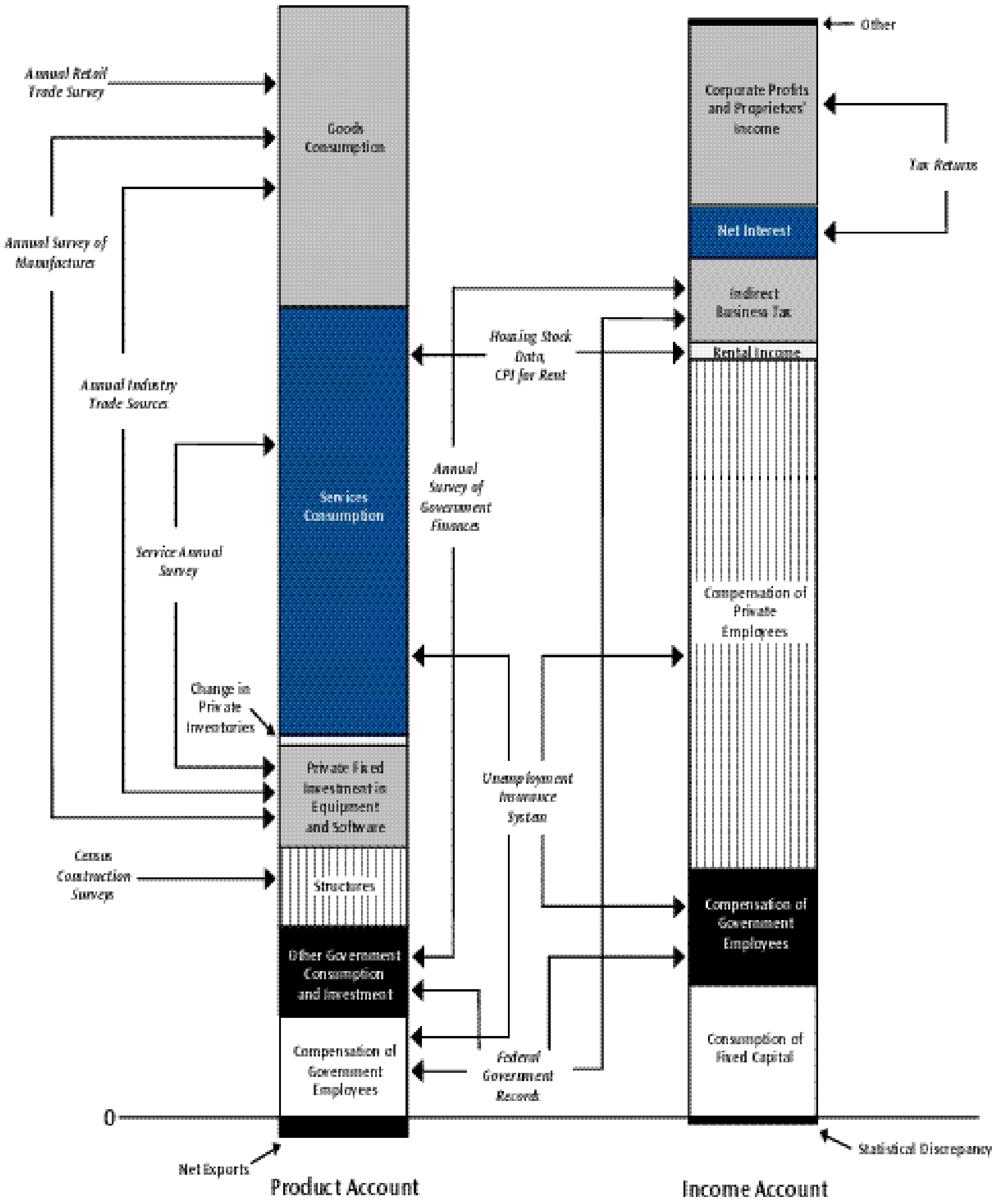


conducted every 10 years, provides a benchmark for the number of occupied housing units. In other years, the American Housing Survey, conducted every other year, and the monthly Current Population Survey are used to update the occupied housing figures.

For rented housing, the dollar value of the service flow is obtained by multiplying the tenant-occupied housing stock by average rent, which is collected in the Census of Housing or the American Housing Survey. In years when neither of those surveys is available, rent is extrapolated from the previous value using the change in the CPI for residential rent. (The CPI data also are used for quarterly NIPA estimates.)

Owner-occupied housing services are handled in the same way, though a rental rate must be imputed. This is done using actual rents on comparable rented dwellings from the Census of Housing. In other years, and for quarterly estimates, the change in average imputed rent is based on the change in the CPI for homeowners' equivalent rent, which is itself based on the monthly CPI Housing Survey. ${ }^{8}$

The Service Annual Survey, with a sample of about 30,000 service businesses, provides the basic data for roughly another $\$ 1.2$ trillion of consumption expenditures in various categories. One of the largest of these service categories is professional medical services.

Annual surveys of state and local governments generate data on publicly provided services such as public hospitals, state universities, and municipal water systems. ${ }^{9}$

The data sources for the remainder of services consumption (roughly half of the total) are difficult to summarize. They include a wide variety of sources such as regulatory agencies, trade sources, and wages and salaries of employees engaged in a particular activity (collected as part of state unemployment insurance programs).

\section{Private Investment}

Investment in residential and nonresidential structures, about $\$ 633$ billion in 1998 , is based on the value of construction put in place, reported by the Census Bureau. ${ }^{10}$ Residential value put in place comes from the Census Bureau's Housing Starts Survey and Housing Sales Survey. Nonresidential value is based primarily on the Census Bureau's Construction Progress Reporting Survey. In each case, the survey respondent is the owner of the project or, occasionally, the general contractor.

Except for autos, trucks, and aircraft, estimates of investment in equipment and software are based on manufacturers' shipments reported in the Annual Survey of Manufactures. The Service Annual Survey is the primary source for data on software investment (\$123 billion in 1998). ${ }^{11}$ Investment in equipment and software, excluding autos, totaled about $\$ 786$ billion in 1998. Autos and trucks are handled in the same way as those that show up in consumption. Aircraft investment is based on shipments reported by manufacturers to the Census Bureau, adjusted for imports and exports.

Most of the change in private inventories is associated with manufacturing and trade. Businesses in these sectors are asked about end-of-year inventories in the Annual Retail Trade Survey, the Annual Wholesale Trade Survey, and the Annual Survey of Manufactures.

\section{Government Consumption and Investment Expenditures}

Not surprisingly, data on federal expenditures come from the federal government in one way or another. Most of the complications here come from translating budgetary concepts into NIPA concepts and budget-year data into calendar-year data.

The largest single input to NIPA calculations of federal consumption expenditures is civilian wages and benefits, reported by the Office of Personnel Management. Compensation is the largest component of state and local expenditures as well. The same entries for compensation of government employees show up on the income side of the accounts under compensation of employees. (The data sources are discussed below under that heading.) The compensation of government employees is the largest component of the NIPA for which corresponding entries on the income and product sides of the accounts do not come from separate sources (see Figure 3). This deviation from the

\footnotetext{
${ }^{8}$ Homeowners' equivalent rent is based on the question, "How much do you think you could rent this house out for monthly, not including utilities?" For details, see Bureau of Labor Statistics (1997), chapter 17. Notice that the question and answer refer to the homeowner's opinion, not to market transactions (the generally preferred, but in this case unavailable, data source for the NIPA).

${ }^{9}$ Public elementary and secondary education falls under government consumption, since it is paid for almost exclusively by governments.

10 "Value of construction put in place" is the value of construction work completed on a project, regardless of whether the project itself is completed

${ }^{11}$ Software purchased by businesses and government was reclassified as investment in the comprehensive NIPA revisions released in October 1999
} 
usual principle is necessary because the output of government activities is not generally marketed, and for most government activities there is no closely related private activity. Consequently, there are no market prices to use in valuing the output of government, and no good way to impute the value. $^{12}$ (By comparison, owner-occupied housing is not marketed, but comparable rental housing provides a reasonable basis for imputation.) Instead, cost serves as a proxy for output in the government sector.

A similar issue arises for government consumption of fixed capital (economic depreciation). ${ }^{13}$ In the private sector, the fixed capital that is "used up" during the year produces output that is measured separately in the product account (canning machines produce canned peas, for example). Since the output of government capital is typically not sold and, therefore, not measured, consumption of government fixed capital is entered in both the product and income accounts to maintain the internal consistency of the accounts. (The data sources are discussed below under Consumption of Fixed Capital.) In other words, cost (depreciation in this case) again serves as a proxy for output.

State and local structures investment is based on the same construction surveys that are used for private investment in structures. The remainder of state and local consumption and investment expenditures are based primarily on information from the Census Bureau Annual Survey of Government Finances.

\section{Net Exports}

Exports and imports of goods ( $\$ 681$ billion and $\$ 930$ billion, respectively, for 1998) are based on compilations of documents collected by the Customs Service. In principle, these documents cover all goods that are exported or imported, but there are significant under-reporting problems, particularly for exports. ${ }^{14}$ Estimates of trade in services (exports, $\$ 285$ billion; imports, $\$ 186$ billion) are based on a number of BEA surveys of potential domestic importers and exporters.

\section{THE INCOME ACCOUNT}

\section{Compensation of Employees}

For most industries and for state and local governments, wages and salaries data come primarily from state unemployment insurance agencies (ES202 data). Employers are required to report this data as part of the unemployment insurance system. This one source accounted for about 78 percent of compensation, or 45 percent of GDP in 1998. As mentioned earlier, federal civilian compensation is based on administrative data from the Office of Personnel Management. Military compensation is based on the Budget of the United States.

Employer contributions for social insurance come mostly from the agencies administering various social insurance programs (the Social Security Administration, for example).

The largest components of other labor income are employer contributions for group health insurance (\$274 billion in 1998) and employer contributions to pension and profit-sharing plans $(\$ 187$ billion in 1998). ${ }^{15}$ The Health Care Financing Administration assembles data on total health insurance contributions, primarily from trade sources. The portion paid by employees (classified as consumption, not part of compensation) is based on the Consumer Expenditure Survey, which asks households to track all of their expenditures. (The Consumer Expenditure Survey also is used to determine how to weight different prices in assembling the CPI.) Employer contributions for group health insurance are calculated as the difference between total and employee contributions. An exception: Because of data availability lags, data from Bureau of Labor Statistics' (BLS) compensation surveys are used for the most recent three years of employer group health insurance contributions. (These are the same surveys of employers used to produce the Employment Cost Index.)

\footnotetext{
${ }^{12}$ One implication is that using NIPA output data to calculate the labor productivity (output per hour) of government employees is meaningless. The same is true of the service industries mentioned earlier, for which output is estimated using primarily compensation of employees

${ }^{13}$ Beginning in 1995, the NIPA handling of government activities was refined to treat government consumption and investment separately. Previously all government purchases were treated as consumption, so there was no calculation of depreciation for government.

${ }^{14}$ Trade with Canada, the United States' largest trading partner, is a special case. Import information is generally scrutinized more thoroughly by customs officials because of tariffs, quotas, and so forth. Consequently, import data are generally more reliable than export data. U.S. exports to Canada in the NIPA are based on Canadian imports from the United States.

${ }^{15}$ Before the comprehensive NIPA revisions released in October 1999 public pensions were treated as social insurance funds in the government sector.
} 
Data on private pensions and profit-sharing also come from the BLS compensation surveys, and from regulatory data reported to the Internal Revenue Service and Department of Labor. For public employees, the sources are Census Bureau surveys of state and local retirement funds, and the federal Office of Personnel Management.

\section{Corporate Profits and Proprietors' Income}

The primary data source for calculation of corporate profits (\$846 billion in 1998) and nonfarm proprietors' income ( $\$ 532$ billion in 1998) is Internal Revenue Service tabulations of business tax returns.

\section{Rental Income of Persons}

Most of rental income is the income-account counterpart of the imputed space rent on owneroccupied housing, adjusted for expenses. ${ }^{16}$ The imputed services of owner-occupied housing are, therefore, another example of a product-account component whose income-account counterpart is based on the same data source. The largest of the expenses, mortgage interest, is subtracted here, but reappears under net interest. ${ }^{17}$ The required mortgage debt data come from the Federal Reserve Board. Rents from tenant-occupied housing are handled in the same way, but appear here only if they accrue to a person not primarily engaged in the real estate business, otherwise they are classified as proprietors' income or corporate profits.

\section{Net Interest}

Except for mortgage interest, estimates of net monetary interest paid by business are based on Internal Revenue Service tabulations from business tax returns.

Most of the net interest component of national income is composed of imputations, however. Financial businesses such as banks and life insurance companies invest depositors' or policyholders' funds in various ways that earn returns, but what they provide to depositors or policyholders is not necessarily a monetary return. A bank, for example, may provide only checking services and no monetary interest in exchange for the use of deposits in a checking account. Another bank might pay interest on checking accounts, but levy an explicit service charge for checking services. In either case the bank is "producing" checking services that should be counted in GDP. The impu- tations capture the value of the services provided "free" in the first case. (The corresponding entry in the product account is "financial services furnished without payment," a $\$ 218$ billion entry under services consumption.) These imputations are based mainly on information reported to regulatory agencies (the Federal Reserve, for example).

\section{Indirect Business Taxes}

Indirect business tax and nontax liabilities (\$677 billion) come directly from federal government sources and for state and local taxes from the Annual Survey of Government Finances.

\section{Consumption of Fixed Capital}

Consumption of fixed capital (economic depreciation) estimates for both government and the private sector are based on perpetual-inventory calculations, which work roughly as follows. Physical or software capital accumulates during each period through gross investment (as measured by the NIPA). Capital consumption is calculated by applying different depreciation rates to the stock of each type of physical capital.

\section{QUARTERLY ESTIMATES}

This section provides a brief summary of the differences in sources between quarterly and annual NIPA estimates. It is useful to keep in mind that estimates for recent quarters differ in two ways from estimates for quarters in past years. First, estimates for the most recent quarter are based on much less complete information. Estimates for a given quarter are first released during the first month of the following quarter (advance estimates), and often change substantially during the next two months (preliminary and final estimates). ${ }^{18}$ Second, the most recent quarters are

\footnotetext{
${ }^{16}$ The expenses show up elsewhere in the income account as, for example, plumber's income.

${ }^{17}$ There is a tricky accounting convention hidden here. In the NIPA, homeownership is treated as a business so that owned and rented housing will be treated symmetrically. This implies that mortgage interest is subtracted as an expense in rental income and added as monetary interest paid by business under net interest. Therefore, it has no net effect on GDP.

${ }^{18}$ Grimm and Parker (1998) discuss the reliability of early quarterly estimates of real GDP.
} 
extrapolations from the most recent annual estimate, while quarterly estimates from, say, 1996, have been revised for consistency with the annual estimates for 1996.

Except for relatively short delays in data availability, the following NIPA components are based on largely the same sources for both quarterly and annual estimates: auto purchases, investment in residential and nonresidential structures, most federal expenditures, and international trade in goods.

Quarterly estimates for most of goods consumption are derived from the Monthly Retail Trade Survey, which uses a much smaller sample than the annual survey.

Quarterly estimates of compensation depend primarily on the BLS' Monthly Payroll Survey (BLS790). BLS annually benchmarks the payroll survey to the data from the unemployment insurance system (ES-202) used for annual estimates: The March employment totals in the payroll survey are adjusted to the totals in the less punctual but far more comprehensive ES-202 data. This, of course, induces later revisions to the NIPA. In addition to more accurate employment data, the ES-202 data include earnings for all nonagricultural employees. The payroll survey, however, reports employment for all employees but earnings for only production and nonsupervisory employees (82 percent of private employees during 1999).

In BEA descriptions of quarterly estimates for services consumption, and for many smaller components of the income side of the accounts, the phrase "judgmental trend" figures prominently, particularly for early estimates. The phrase refers to a range of less formal approaches that are used prior to the availability of actual data. BEA tries to choose techniques that do not produce systematic errors. Typically, the judgmental trend applies to changes in quantities, while components of the CPI (which are rapidly available) are used to estimate price change. For example, early estimates of housing services are based on a judgmental trend for the housing stock, combined with actual data on rents from the CPI. For a number of service categories, quantity change is estimated using employment change in the industry providing the service.

Quarterly investment in equipment and software, except motor vehicles and aircraft, is based on the monthly Manufacturers' Shipments, Inventories, and Orders (M3) Survey, which is regu- larly revised for consistency with the Annual Survey of Manufactures.

Quarterly corporate profits estimates are based partly on the Census Bureau's Quarterly Financial Report, a survey of manufacturing, mining, and trade corporations. Publicly available corporate financial statements and information from regulatory agencies (public utilities commissions, for example) underlie the estimates for other sectors.

\section{REAL GDP}

Although accounting for the effects of price change on the NIPA - that is, the construction of quantity indexes or, informally, real GDP - has been the subject of considerable controversy, describing the data sources is surprisingly easy.

Most components of personal consumption expenditures are deflated using components of the CPI. ${ }^{19}$ According to Eldridge (1999), CPI components were used to deflate 49.7 percent of 1997 current-dollar GDP, primarily personal consumption expenditures. Most of the components of investment in equipment and software, as well as change in private inventories, are deflated using components of the Producer Price Index (PPI). For items other than housing, BLS personnel collect price data directly from a sample of retail outlets for the CPI, while surveyed producers report transaction prices for the PPI. The Census Bureau and BEA create special construction price indexes for structures investment (private and government) with data from the same construction surveys used in estimating the nominal value of construction.

A number of other specialized price indexes are used to deflate smaller components of GDP, but most of the remainder of real GDP is estimated by directly using quantity information. One important example illustrates the principle: As mentioned above, a big piece of government consumption corresponds to compensation of government employees. The same sources that provide dollar compensation for use in estimating nominal GDP also provide data on the number of government employees. Changes in the real GDP component (quantity index) primarily reflect changes in government employment (labor input), although BEA

\footnotetext{
${ }^{19}$ Many quality adjustments, such as accounting for improvements in automobile safety, are embedded in the low-level CPI aggregates. Thus, much of the debate over quality change in the CPI is largely germane to the estimation of real consumption. For details see Triplett (1997).
} 
adjusts for changes in hours worked and in the composition of government employment.

\section{CONCLUSION}

The successful tracking of the U.S. economy through the NIPA is an astounding feat. Nevertheless, closer acquaintance with the data sources behind the accounts highlights at least two facts: (1) There is considerable, but not well understood, uncertainty about exact magnitudes of various aggregate quantities and their growth rates; this is one reason sophisticated observers of the economy do not rely exclusively on GDP growth rates to evaluate the health of the economy. (2) Ongoing evaluation of the data-collection efforts that support the accounts is needed to maintain the reliability of the accounts and to allow them to evolve in response to changes in the economy.

\section{REFERENCES}

Abel, Andrew B., and Ben S. Bernanke. Macroeconomics, 3rd edition, Addison-Wesley, 1997.

Bureau of Labor Statistics. BLS Handbook of Methods, U.S. Government Printing Office, April 1997. Also available at $<$ http://bls.gov/opub/hom/homtoc_pdf.htm $>$.

Eldridge, Lucy P. "How Price Indexes Affect BLS Productivity Measures," Monthly Labor Review (February 1999), pp. 35-46. Also available at <http://www. bls.gov/opub/mlr/1999/02/art3full.pdf $>$.

Grimm, Bruce T., and Robert P. Parker. "Reliability of the Quarterly and Annual Estimates of GDP and Gross Domestic Income," Survey of Current Business (December 1998), pp. 12-21. Also available at <http://www.bea.doc. gov/bea/ARTICLES/NATIONAL/NIPA/1998/1298od.pdf $>$.

Haltiwanger, John C. "Measuring and Analyzing Aggregate Fluctuations: The Importance of Building from Microeconomic Evidence," this Review (May/June 1997), pp. 55-75. Also available at <http://www.stls.frb.org/docs/ publications/review/97/05/9705jh.pdf $>$.

Mankiw, N. Gregory. Macroeconomics, 4th edition, Worth Publishers Inc., 1999.

Romer, Christina D. "Changes in Business Cycles: Evidence and Explanations," Journal of Economic Perspectives (Spring 1999), pp. 23-44.

Seskin, Eugene P., and Robert P. Parker. "A Guide to the NIPA's," Survey of Current Business (March 1998), pp. 2668. Also available at $<$ http://www.bea.doc.gov/bea/ARTICLES/NATIONAL/NIPA/1998/0398niw.pdf $>$.

Triplett, Jack E. "Measuring Consumption: The Post-1973 Slowdown and the Research Issues," this Review (May/June
1997), pp. 9-42. Also available at $<$ http://www.stls.frb.org/ docs/publications/review/97/05/9705jt.pdf $>$.

U.S. Department of Commerce, Bureau of Economic Analysis. "Updated Summary NIPA Methodologies," Survey of Current Business (September 1998), pp. 14-35. Also available at $<$ http://www.bea.doc.gov/bea/ARTICLES/ NATIONAL/NIPA/1998/0998niw.pdf $>$.

U.S. Department of Commerce, Bureau of Economic Analysis. Personal Consumption Expenditures, Methodology Paper Series, MP-6, Washington, DC. U.S. Government Printing Office, June 1990. Also available at $<$ http://www.bea.doc.gov/bea/ARTICLES/NATIONAL/NIPA/ Methpap/methpap6.pdf $>$. 